\title{
PENGARUH JOB INSECURITY TERHADAP TURNOVER INTENTION DENGAN EMPLOYEE MORALE DAN PSYCHOLOGICAL STRAIN SEBAGAI VARIABEL MEDIASI PADA PROFESI KEPERAWATAN DI JAKARTA
}

\author{
Hutri Mardika RM, Yustinus H Yogatama
}

Bussiness Management Binus University Jakarta, Indonesia

Email: hutrimardikarm@gmail.com, justinyogatama@gmail.com

\begin{abstract}
Abstrak
Pandemi Covid-19 yang berlangsung sejak Maret 2020 di Indonesia sampai dengan saat penelitian ini dilakukan membawa dampak yang luar biasa bagi seluruh industri termasuk juga pelayanan kesehatan secara umum dan Rumah Sakit secara khusus. Dampak ekonomi bagi institusi pelayanan kesehatan yang disebabkan karena penurunan pasien di awal pandemic dan keharusan untuk menyiapkan alat perlindungan diri sehingga harus melakukan efisiensi serta resiko tertular penyakit bagi tenaga kesehatan dan pekerja di Rumah Sakit dapat menimbulkan perasaan tidak aman (job insecurity). Perasaan tersebut mempengaruhi moral kerja (employee morale) dan hambatan psikologis (psychological strain) perawat sebagai garda terdepan dan dapat mencetuskan keinginan untuk undur diri (turnover intention). Kuesioner online diisi oleh 110 perawat yang bekerja di Rumah Sakit-Rumah Sakit di Jakarta, Indonesia pada periode menjelang 1 tahun pandemi Covid-19 (FebruariApril 2021) dihadapi Indonesia. Uji Asumsi Klasik dengan SPSS dan PLS-SEM digunakan untuk mengetahui pengaruh job insecurity terhadap turnover Intention dengan employee morale dan psychological strain sebagai variable mediasi. Dari hasil pengujian didapatkan bahwa job insecurity secara positif mempengaruhi turnover intention pada perawat yang bekerja di Rumah Sakit di Jakarta. Employee morale memediasi hubungan job insecurity dan turnover intention, sementara psychological strain tidak terbukti memediasi hubungan tersebut. Sebagai kesimpulan, bahwa turnover intention perawat yang bekerja di Rumah Sakit di Jakarta 1 tahun setelah pandemic dapat dipengaruhi oleh kondisi job insecurity. Manajemen Rumah Sakit dan pembuat kebijakan juga perlu mempertimbangkan aspek moral kerja dan psikologis bagi tenaga kesehatan terutama perawat sebagai salah satu tenaga kesehatan yang bertugas di garda depan.
\end{abstract}

Kata Kunci: covid-19; pandemi; ketidakamanan pekerjaan; moral karyawan; ketegangan psikologis; hasrat undur diri; perawat; rumah sakit.

\section{Abstract}

The Covid-19 pandemic that has been going on since March 2020 in Indonesia until the time this research was conducted has had a tremendous impact on all industries, including health services in general and hospitals in particular. The economic impact on health care institutions caused by the decline in patients at the beginning of the pandemic and the necessity to prepare personal protective equipment so that they must carry out efficiency and the risk of contracting disease

$\begin{array}{ll}\text { How to cite: } & \text { RM, H, M., Yogatama, Y. H., (2021) Pengaruh Job Insecurity Terhadap Turnover Intention Dengan } \\ & \text { Employee Morale Dan Psychological Strain Sebagai Variabel Mediasi Pada Profesi Keperawatan Di } \\ & \text { Jakarta, Syntax Idea, 3(11), https://doi.org/10.36418/syntax-ideav3i11.1542 } \\ \text { E-ISSN: } & \text { 2684-883X } \\ \text { Published by: } & \text { Ridwan Institute }\end{array}$


for health workers and workers in hospitals can create feelings of insecurity (job insecurity). These feelings affect work morale (employee morale) and psychological barriers (psychological strain) of nurses as the frontline and can trigger a desire to resign (turnover intention). The online questionnaire was filled out by 110 nurses who worked in hospitals in Jakarta, Indonesia in the period leading up to the 1year period of the Covid-19 pandemic (February-April 2021) faced by Indonesia. Classical Assumption Test with SPSS and PLS-SEM was used to determine the effect of job insecurity on turnover intention with employee morale and psychological strain as mediating variables. From the test results, it was found that job insecurity positively affects the turnover intention of nurses who work in hospitals in Jakarta. Employee morale mediates the relationship between job insecurity and turnover intention, while psychological strain is not proven to mediate this relationship. In conclusion, the turnover intention of nurses working in hospitals in Jakarta 1 year after the pandemic can be influenced by job insecurity conditions. Hospital management and policy makers also need to consider the moral and psychological aspects of health workers, especially nurses as one of the health workers on the front line.

Keywords: covid-19; pandemic; job insecurity; employee morale; psychological strain; turnover intention; nurse; hospital

Received: 2021-10-22; Accepted: 2021-11-05; Published: 2021-11-20

\section{Pendahuluan}

Pandemi COVID-19 memiliki dampak yang sangat buruk bagi ketenagakerjaan di Indonesia. Hal ini didasari atas data Kementerian Ketenagakerjaan (Kemnaker) per 7 April 2020, akibat pandemi Covid-19, tercatat sebanyak 39.977 perusahaan di sektor formal yang memilih merumahkan, dan melakukan PHK terhadap pekerjanya. Total ada 1.010.579 orang pekerja yang terkena dampak ini. Melihat dari data tersebut, menunjukkan bagaimana pandemi COVID-19 sangat berdampak negatif terhadap ketenagakerjaan di Indonesia dan hal ini sangat berkaitan dan penting untuk diteliti karena menyangkut masa depan seorang karyawan di perusahaan.

Kebijakan-kebijakan yang dilakukan oleh sebuah perusahaan pada masa pandemi COVID-19 memang berdampak besar terhadap karyawan, dan tentunya tidak semua kebijakan yang diputuskan akan dapat diterima oleh karyawan, seperti kebijakan untuk melakukan lay-off atau merumahkan karyawan tanpa masa depan yang jelas. Kebijakan ini tentunya membuat karyawan merasa tidak mendapatkan kepastian dan akan memunculkan minat karyawan untuk pergi atau berpindah ke perusahaan lain yang mungkin bisa menjamin masa depan mereka walaupun tidak secara keseluruhan.

Minat keluar karyawan yang muncul dapat disebut juga dengan turnover intention. Turnover intention secara definisi adalah kesadaran untuk berpikir, berkeinginan dan berencana untuk meninggalkan pekerjaan (Feng \& Angeline, 2010). Tentunya turnover intention akan sangat merugikan pihak perusahaan karena dengan tingginya tingkat turnover intention, maka perusahaan akan membutuhkan waktu, biaya dan tenaga lagi untuk melakukan rekruitmen pada divisi yang ditinggalkan oleh 
Pengaruh Job Insecurity terhadap Turnover Intention dengan Employee Morale dan Psychological Strain sebagai Variabel Mediasi pada Profesi Keperawatan di Jakarta

karyawan tersebut, terutama pada bidang usaha yang sangat bergantung pada kompetensi khusus seperti di Rumah Sakit.

Merujuk pada penelitian yang dijalankan oleh (Obeng, Quansah, \& Boakye, 2020) dijelaskan bahwa salah satu faktor yang bisa meningkatkan turnover intention adalah job insecurity. Job insecurity sendiri adalah tingkat kekhawatiran karyawan terhadap pekerjaan mereka, baik kekhawatiran akan kehilangan pekerjaan, atau kekhawatiran akan dampak dari pekerjaan yang mereka lakukan. Menurut (Richter, Näswall, \& Sverke, 2010) job insecurity memiliki efek negatif yang terdokumentasi dengan baik bagi individu maupun organisasi. Namun, mekanisme di mana ketidakamanan pekerjaan terkait dengan hasilnya kurang mendapat perhatian penelitian. Tentunya sebagai pekerja di bidang keperawatan, banyak faktor yang bisa menghasilkan job insecurity itu sendiri seperti pandemi COVID-19 yang menular, kelelahan bekerja karena sistem lembur, hingga masa depan mereka yang tidak ada kepastian dengan adanya pandemi serta jalur karier yang jelas. Hal ini tentunya membuat tingkat job insecurity divisi keperawatan akan tinggi. Namun, dugaan ini berlawanan dengan hasil penelitian (Giantari \& Riana, 2017) yang menjelaskan bahwa ternyata job insecurity tidak berpengaruh terhadap turnover intention.

Tentunya, job insecurity yang tinggi tidak serta merta membuat minat keluar karyawan tinggi. Terdapat beberapa faktor yang dapat memicu turnover intention setelah adanya tingkat job insecutiy yang tinggi seperti employee morale yang buruk dan psychological strain yang tinggi. Employee morale merujuk pada segala hal yang membuat orang-orang senang mengabdi kepada pekerjaannya, dimana kepuasan kerja dan hubungan-hubungan kekeluargaan yang menyenangkan menjadi bagian daripadanya (Saputra, Sudiro, \& Irawanto, 2018). Semangat kerja atau employee morale divisi keperawatan di Jakarta bisa saja menjadi faktor yang dipengaruhi oleh job insecurity karena semakin tinggi tingkat job insecurity maka rasa khawatir akan pekerjaan semakin tinggi dan akan membuat karyawan tidak lagi merasa senang dan ingin mengabdi terhadap pekerjaan mereka, terutama dengan kasus COVID-19 yang terus meningkat dikarenakan ketidakdisiplinan masyarakat, membuat employee morale menjadi buruk dan membuat tingkat turnover intention divisi keperawatan di Jakarta meningkat.

Faktor lain yang juga bisa memediasi adalah psychological strain. Psychological strain didefinisikan sebagai reaksi subjektif terhadap faktor stres seperti kecemasan, depresi, kelelahan, dan kehilangan kepercayaan diri. Dengan job insecurity yang tinggi, maka akan memicu rasa stres dan depresi karena rasa khawatir akan mengganggu kejiwaan seseorang dan akan menyebabkan karyawan merasa stres setiap kali bekerja. Dan tentunya, dengan stres inilah akan membuat karyawan mencari jalan keluar, salah satunya adalah dengan keluar dari pekerjaan mereka.

Melihat dari keterkaitan antara variabel yang telah dipaparkan di atas, maka penelitian ini akan dijalankan dengan judul "Pengaruh job insecurity terhadap turnover intention dengan employee morale dan psychological strain sebagai variabel mediasi pada profesi keperawatan di Jakarta". 


\section{Metode Penelitian}

Jenis penelitian yang digunakan dalam penelitian ini adalah penelitian kuantitatif dengan menggunakan pendekatan asosiatif. Metode penelitian kuantitatif merupakan sebuah jenis penelitian yang spesifikasinya adalah berbentuk sistematis, terencana dan juga terstruktur dengan jelas dari awal hingga pembuatan desain penelitiannya. Menurut (Sekaran \& Bougie, 2019), metode penelitian kuantitatif dapat diartikan sebagai sebuah metode penelitian yang pemecahan masalahnya didasari atas perhitungan statistika dan matematika. Dalam penelitian ini, teknik analisis kuantitatif digunakan untuk memaparkan kecenderungan sikap dan opini dari subjek penelitian yang ada dalam suatu wilayah dengan melakukan penelitian beberapa sampel dari populasi tersebut.

Metode asosiatif merupakan penelitian yang bertujuan untuk mengetahui pengaruh atau hubungan antara dua variabel atau lebih dalam sebuah penelitian. Menurut (Sarwono, 2012) penelitian asosiatif adalah sebuah pendekatan dalam penelitian yang digunakan saat peneliti ingin meneliti keterkaitan sebab akibat antara 2 variabel atau lebih. Dalam penelitian ini, metode asosiatif digunakan karena terdapat 3 variabel yang dianggap sebagai prediktor yaitu job insecurity, psychological strain dan employee morale.

Menurut (Sugiyono, 2015) menjelaskan bahwa populasi merupakan wilayah generalisasi yang terdiri atas subyek atau obyek yang memiliki sebuah karakter dan kualitas tertentu yang ditetapkan oleh peneliti untuk dipelajari dan kemudian menjadi sebuah kesimpulan. Populasi dapat menjadi keseluruhan dalam sebuah obyek penelitian sehingga populasi itu luas dan lebih besar dari jumlah sampel. Populasi yang digunakan pada penelitian ini adalah profesi perawat yang bekerja di Rumah Sakit di Jakarta.

Berdasarkan Profil Kesehatan DKI Jakarta 2019, BPS DKI Jakarta tahun 2019, terdapat 135 Rumah Sakit Umum dan 51 Rumah Sakit Khusus, serta 19 RS Bersalin/RB. Menurut www.katadata.co.id tahun 2019, jumlah seluruh perawat yang tersebar di Propinsi DKI Jakarta pada tahun 2019 adalah 26.950 orang. Yang menjadi sampel dalam penelitian ini adalah sebagian dari perawat yang bekerja di Rumah Sakit di Jakarta.

Menurut (Sugiyono, 2015) mendefinisikan sampel sebagai bagian dari jumlah dan karakteristik yang dimiliki oleh sebuah populasi dan harus bersifat representatif atau mewakili dari populasi tersebut. Teknik pengambilan sampel yang digunakan pada penelitian ini adalah non-probability sampling dengan pendekatan purposive sampling. Menurut (Sekaran \& Bougie, 2019), metode non-probability sampling adalah metode pengambilan sampel dimana tidak seluruh populasi memiliki kesempatan yang sama untuk menjadi sampel. Pendekatan yang digunakan dalam penelitian ini adalah purposive sampling yaitu pendekatan dimana dalam penentuannya, sampel harus memenuhi kriteria-kriteria tertentu (Sugiyono, 2015). Metode ini dipilih karena peneliti mengalami kendala untuk mendapatkan data detil dari seluruh populasi tersebut.

Dalam penelitian ini, untuk menghitung jumlah sampel, digunakan rumus Slovin sebagai berikut: 
Pengaruh Job Insecurity terhadap Turnover Intention dengan Employee Morale dan Psychological Strain sebagai Variabel Mediasi pada Profesi Keperawatan di Jakarta

$$
\mathrm{n}=\frac{\mathrm{N}}{1+\mathrm{Ne}^{2}}
$$

Dimana:

$\mathrm{n} \quad=$ jumlah sampel

$\mathrm{N}=$ jumlah populasi

$\mathrm{e}=$ presisi atau peran kelonggaran ketidaktelitian karena kesalahan pengambilan sampel yang masih dapat ditolerir atau diinginkan, yaitu sebesar 5\% atau 0,05 (Sugiyono, 2017).

Berdasarkan rumus Slovin di atas, maka jumlah sampel yang diambil dalam penelitian ini sebesar:

$$
\begin{gathered}
\mathrm{N}=26.950 ; \quad \mathrm{e}=5 \% \% \\
n=\frac{26.950}{1+26.950(0,05)^{2}} \\
\mathrm{n}=399,98=\mathbf{4 0 0}
\end{gathered}
$$

Jadi, yang akan menjadi sampel pada penelitian ini adalah 400 perawat yang bekerja di Jakarta.

Sumber data yang dipakai dalam penelitian ini merupakan data primer. Menurut (Sekaran \& Bougie, 2019), data primer mengacu pada data yang diperoleh oleh peneliti dari tangan pertama yang berhubungan dengan variabel yang diteliti oleh peneliti untuk tujuan spesifik studi. Selanjutnya, skala yang digunakan pada penelitian ini adalah skala ordinal dimana skala ordinal merupakan skala yang diwakilkan dengan sebuah angka yang selain berfungsi sebagai skala nominal yang merupakan lambang atau simbol untuk membedakan, skala ordinal juga berfungsi untuk mengetahui bahwa sesuatu lebih baik atau buruk daripada yang dibandingkan akan tetapi tidak sampai beberapa kali.

Dalam penelitian ini, skala ordinal digunakan dengan menggunakan skala likert yang terdiri dari 5 skala yaitu sangat tidak setuju (1), tidak setuju (2), ragu-ragu (3), setuju (4), dan sangat setuju (5) menjelaskan bahwa sangat setuju lebih baik dari setuju, setuju lebih baik dari ragu-ragu, dan seterusnya. Penggunaan skala ini sesuai dengan definisi skala ordinal yang menunjukkan sesuatu lebih baik atau buruk dari yang lain. (Sekaran \& Bougie, 2019). Selain itu, penelitian ini akan menggunakan metode pengolahan data Partial Least Square yang berbeda dengan regresi berganda pada umumnya dikarenakan dengan Partial Least Square tidak diperlukan metode untuk mengintervalkan data (Ramayah, Cheah, Chuah, Ting, \& Memon, 2018).

Metode pengumpulan data yang digunakan pada penelitian ini adalah dengan berbentuk kuesioner. Menurut (Sugiyono, 2015), kuesioner merupakan teknik pengumpulan data yang dilakukan dengan cara memberikan seperangkat pertanyaan atau pernyataan tertulis kepada para responden untuk dijawab. Terdapat dua puluh satu pertanyaan yang terdapat pada kuesioner yang disebarkan kepada perawat yang bekerja di Rumah Sakit di Jakarta. 


\section{Hasil dan Pembahasan}

\section{A. Hasil Penelitian}

\section{Uji Asumsi Klasik dengan SPSS}

Analisa uji asumsi klasik dengan SPSS kami lakukan dengan tujuan untuk menunjukkan dan memperoleh hasil yang lebih valid dengan pertimbangan jumlah sample yang tidak mencapai jumlah target sample.

\section{1) Uji Outlier}

Uji Outlier merupakan observasi dari suatu sample apakah terdapat suatu data yang memiliki karakteristik unik yang terlihat berbeda dengan data yang lainnya (Nasehudin \& Gozali, 2012). Untuk melihat data yang abnormal tersebut, dapat dilihat dari nilai MAH, jika jumlah sample N:100 maka batas maksimal MAH-nya adalah 15, sehingga jika nilainya di atas 15 maka data tersebut disebut Outliers/abnormal. Apabila terjadi outliers, data tersebut dapat dikeluarkan dari analisis. Berikut hasil uji outliernya :

Tabel 1

Uji Outliers

\begin{tabular}{cccccccc}
\hline \multicolumn{7}{c}{ Hasil Uji Outliers } \\
\hline No & MAH_1 & COO_1 & LEV_1 & No & MAH_1 & COO_1 & LEV_1 \\
\hline 1 & 9,38715 & 0,07086 & 0,08612 & 56 & 8,04006 & 0,00133 & 0,07376 \\
\hline 2 & 1,08783 & 0,01065 & 0,00998 & 57 & 2,64788 & 0,00017 & 0,02429 \\
\hline 3 & 0,49681 & 0,00684 & 0,00456 & 58 & 5,16754 & 0,00117 & 0,04741 \\
\hline 4 & 2,04363 & 0,01513 & 0,01875 & 59 & 2,31273 & 0,00034 & 0,02122 \\
\hline 5 & 1,33693 & 0,01157 & 0,01227 & 60 & 2,04132 & 0 & 0,01873 \\
\hline 6 & 4,72255 & 0,02123 & 0,04333 & 61 & 2,4396 & 0,00144 & 0,02238 \\
\hline 7 & 2,32253 & 0,00906 & 0,02131 & 62 & 2,95107 & 0,00013 & 0,02707 \\
\hline 8 & 4,05873 & 0,01273 & 0,03724 & 63 & 5,00281 & 0,00014 & 0,0459 \\
\hline 9 & 2,67528 & 0,01703 & 0,02454 & 64 & 1,16229 & 0,00034 & 0,01066 \\
\hline 10 & 0,62282 & 0,00626 & 0,00571 & 65 & 7,40834 & 0,00386 & 0,06797 \\
\hline 11 & 2,26983 & 0,00838 & 0,02082 & 66 & 2,8196 & 0,00288 & 0,02587 \\
\hline 12 & 10,01677 & 0,02093 & 0,0919 & 67 & 2,31698 & 0,00081 & 0,02126 \\
\hline 13 & 13,65909 & 0,07483 & 0,12531 & 68 & 3,31944 & 0,00031 & 0,03045 \\
\hline 14 & 10,3232 & 0,03876 & 0,09471 & 69 & 2,57993 & 0,00166 & 0,02367 \\
\hline 15 & 1,16835 & 0,00469 & 0,01072 & 70 & 2,51788 & 0,00478 & 0,0231 \\
\hline 16 & 0,96004 & 0,00569 & 0,00881 & 71 & 6,01378 & 0,0017 & 0,05517 \\
\hline 17 & 3,17989 & 0,00661 & 0,02917 & 72 & 11,72929 & 0,00019 & 0,10761 \\
\hline 18 & 1,69459 & 0,00531 & 0,01555 & 73 & 5,18195 & 0,00684 & 0,04754 \\
\hline 19 & 2,28377 & 0,01433 & 0,02095 & 74 & 1,94295 & 0,0036 & 0,01783 \\
\hline 20 & 1,76034 & 0,00573 & 0,01615 & 75 & 22,17061 & 0,00023 & 0,2034 \\
\hline 21 & 6,21441 & 0,01824 & 0,05701 & 76 & 2,01366 & 0,00436 & 0,01847 \\
\hline 22 & 1,50501 & 0,00331 & 0,01381 & 77 & 3,29526 & 0,0064 & 0,03023 \\
\hline 23 & 3,63126 & 0,00906 & 0,03331 & 78 & 4,5824 & 0,00096 & 0,04204 \\
\hline 24 & 0,54293 & 0,00201 & 0,00498 & 79 & 9,24546 & 0,00528 & 0,08482 \\
\hline 25 & 4,64447 & 0,00408 & 0,04261 & 80 & 0,23498 & 0,00163 & 0,00216 \\
\hline 26 & 5,27332 & 0,01684 & 0,04838 & 81 & 0,68117 & 0,00138 & 0,00625 \\
\hline & & & & & & & \\
\hline
\end{tabular}


Pengaruh Job Insecurity terhadap Turnover Intention dengan Employee Morale dan Psychological Strain sebagai Variabel Mediasi pada Profesi Keperawatan di Jakarta

\begin{tabular}{cccccccc}
\hline \multicolumn{7}{c}{ Hasil Uji Outliers } \\
\hline 27 & 2,94667 & 0,00267 & 0,02703 & 82 & 4,02812 & 0,01085 & 0,03696 \\
\hline 28 & 5,07264 & 0,01619 & 0,04654 & 83 & 0,50618 & 0,00237 & 0,00464 \\
\hline 29 & 4,54194 & 0,01409 & 0,04167 & 84 & 2,95796 & 0,0038 & 0,02714 \\
\hline 30 & 2,81839 & 0,0092 & 0,02586 & 85 & 4,56194 & 0,00421 & 0,04185 \\
\hline 31 & 6,21441 & 0,00918 & 0,05701 & 86 & 0,80634 & 0,00234 & 0,0074 \\
\hline 32 & 3,49929 & 0,0011 & 0,0321 & 87 & 4,83576 & 0,00923 & 0,04436 \\
\hline 33 & 1,74661 & 0,00172 & 0,01602 & 88 & 6,73334 & 0,01472 & 0,06177 \\
\hline 34 & 1,61802 & 0,00182 & 0,01484 & 89 & 0,54612 & 0,00443 & 0,00501 \\
\hline 35 & 2,81839 & 0,00674 & 0,02586 & 90 & 3,60338 & 0,00725 & 0,03306 \\
\hline 36 & 2,48058 & 0,00051 & 0,02276 & 91 & 3,94363 & 0,01307 & 0,03618 \\
\hline 37 & 3,53906 & 0,00041 & 0,03247 & 92 & 7,65538 & 0,00666 & 0,07023 \\
\hline 38 & 6,54582 & 0,00026 & 0,06005 & 93 & 7,76435 & 0,01295 & 0,07123 \\
\hline 39 & 5,59931 & 0,00747 & 0,05137 & 94 & 5,50397 & 0,02378 & 0,0505 \\
\hline 40 & 8,39841 & 0,02698 & 0,07705 & 95 & 1,46543 & 0,00786 & 0,01344 \\
\hline 41 & 5,96515 & 0,00099 & 0,05473 & 96 & 6,90344 & 0,0182 & 0,06333 \\
\hline 42 & 1,51756 & 0,00039 & 0,01392 & 97 & 0,85727 & 0,00457 & 0,00786 \\
\hline 43 & 2,85632 & 0,00329 & 0,0262 & 98 & 0,56037 & 0,006 & 0,00514 \\
\hline 44 & 2,80125 & 0,00169 & 0,0257 & 99 & 1,89224 & 0,00886 & 0,01736 \\
\hline 45 & 5,99776 & 0,00223 & 0,05503 & 100 & 2,32253 & 0,0205 & 0,02131 \\
\hline 46 & 7,71922 & 0,0059 & 0,07082 & 101 & 9,74451 & 0,0215 & 0,0894 \\
\hline 47 & 2,7133 & 0 & 0,02489 & 102 & 4,28319 & 0,03346 & 0,0393 \\
\hline 48 & 2,12423 & 0,00038 & 0,01949 & 103 & 6,72719 & 0,03707 & 0,06172 \\
\hline 49 & 2,77456 & 0,00026 & 0,02545 & 104 & 5,13955 & 0,0209 & 0,04715 \\
\hline 50 & 1,12074 & 0 & 0,01028 & 105 & 3,63028 & 0,03583 & 0,03331 \\
\hline 51 & 2,33499 & 0,00164 & 0,02142 & 106 & 11,70218 & 0,02379 & 0,10736 \\
\hline 52 & 0,96368 & 0,00026 & 0,00884 & 107 & 1,72264 & 0,00933 & 0,0158 \\
\hline 53 & 0,96368 & 0,0002 & 0,00884 & 108 & 0,50618 & 0,00829 & 0,00464 \\
\hline 54 & 0,61778 & 0,00001 & 0,00567 & 109 & 1,59808 & 0,01426 & 0,01466 \\
\hline 55 & 1,55604 & 0,00029 & 0,01428 & 110 & 5,93219 & 0,06744 & 0,05442 \\
\hline & & & &
\end{tabular}

\section{Sumber: Hasil pengolahan data}

Dari Tabel 1, terlihat di kolom MAH terdapat 1 responden dengan nilai $\mathrm{MAH}>15$, yaitu responden dinomor 75 dengan nilai 22,17. Dengan adanya outliers ini, agar hasil semakin valid maka peneliti mengeluarkan sample nomor 75 untuk kemudian di uji dengan Smart PLS.

2) Uji Normalitas

Uji normalitas dilakukan untuk memastikan bahwa data yang diteliti telah memenuhi persyaratan normalitas atau tidak ada data outlier atau data extrim dalam penelitian. Uji normalitas dilakukan dengan menggunakan uji normalitas histogram (Grafik 1) dan normal P-P Plot (Grafik 2) kemudian dikonfirmasi lagi dengan menggunakan Uji Kolmogorov-Smirnov (K-S) one sample (table 2).

Dengan menggunakan grafik histogram di bawah, dapat tergambar pola distribusi data tidak melenceng ke kiri dan ke kanan, sehingga bisa disimpulkan memiliki distribusi normal. 


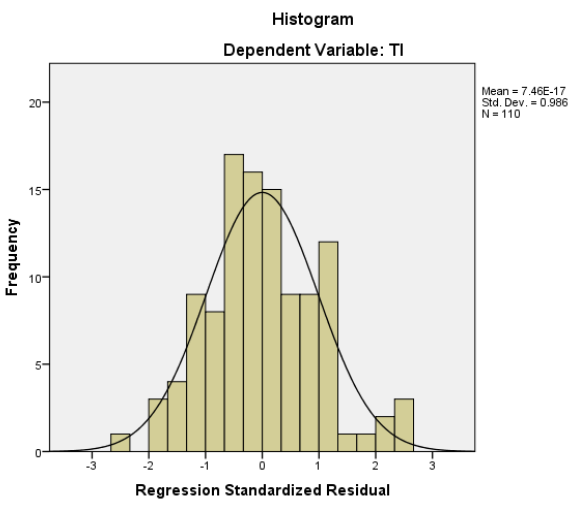

Grafik1

Histogram Uji Normalitas Sample

Sumber: Hasil pengolahan data

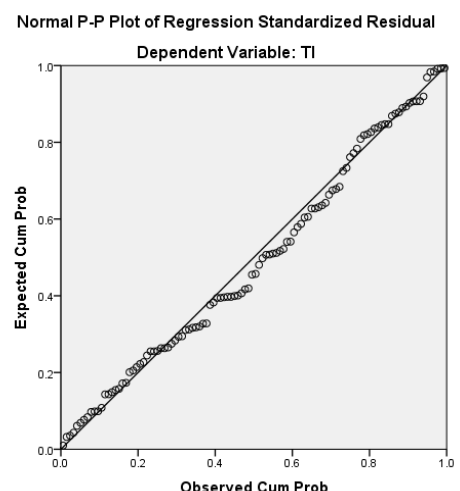

Grafik 2

Normal P-P Plot

Begitu pula pola penyebaran titik-titik pada uji normalitas P-P Plot yang ditunjukkan pada grafik 2 yang mana penyebarannya berada di sekitar atau mendekati garis diagonal, kedua gambaran ini baik histogram dan normal P-P Plot menggambarkan bahwa data penelitian ini memiliki distribusi data normal.

Tabel 2

One-Sample Kolmogorov-Smirnov Test

\begin{tabular}{|c|c|c|}
\hline \multicolumn{3}{|c|}{ Unstandardized Residual } \\
\hline $\mathbf{N}$ & & 110 \\
\hline \multirow[t]{2}{*}{ Normal Parameters ${ }^{\mathrm{a}, \mathrm{b}}$} & Mean & .0000000 \\
\hline & Std. Deviation & 2.89482376 \\
\hline \multirow{3}{*}{ Most Extreme Differences } & Absolute & .073 \\
\hline & Positive & .073 \\
\hline & Negative & -.040 \\
\hline Test Statistic & & .073 \\
\hline
\end{tabular}


Pengaruh Job Insecurity terhadap Turnover Intention dengan Employee Morale dan Psychological Strain sebagai Variabel Mediasi pada Profesi Keperawatan di Jakarta

Tabel 2

One-Sample Kolmogorov-Smirnov Test

Unstandardized Residual

Asymp. Sig. (2-tailed) $.200^{\mathrm{c}, \mathrm{d}}$

a. Test distribution is Normal.

b. Calculated from data.

c. Lilliefors Significance Correction.

d. This is a lower bound of the true significance.

\section{Sumber: Hasil pengolahan data}

Normalitas data yang tergambar pada kedua grafik di atas dilakukan konfirmasi dengan melakukan Uji Kolmogorov-Smirnov one sample dengan hasil pada table 2. Syarat dari uji normalitas Kolmogorov-Smirnov (K-S) one sample adalah sig > .05. Dari hasil uji yang ditunjukkan pada table di atas, terlihat bahwa nilai Asymp. Sig $=.200>0.05$ yang berarti data yang digunakan dalam penelitian ini memiliki distribusi normal.

Dari 3 uji normalitas yaitu grafik histogram, uji normal P-P plot, dan uji Kolmogorov-Smirnov (K-S) one sample dapat dilihat bahwa sample yang diteliti memiliki distribusi normal, yang ditunjukkan dengan pola grafik histogram (grafik 1) dengan distribusi normal dengan mean $=7,46$ dan standar deviasi 0,968. Pola persebaran titik-titik grafik normal p-p plot juga mendekati garis diagonal. Distribusi normal juga dikonfirmasi dengan hasil uji K-S one sample, dengan hasil Asymp.Sig (2-tailed) $=.200$ (mean $=.0000000$, std. deviasi $=$ 2,895).

\section{3) Uji Multikolinearitas}

Uji multikolinearitas bertujuan untuk mengetahui apakah model regresi pada penelitian ini ditemukan adanya korelasi antar variabel independent atau variable bebas. Efek dari multikolinearitas ini menyebabkan tingginya variabel pada sampel. Syarat dari uji mulikolinearitas adalah nilai VIF $<10$ dan nilai tolerance > 0.1 (Nasehudin \& Gozali, 2012). Berikut table hasil pengujian multikolinearitas:

Tabel 3

Uji Multikolinearitas

\begin{tabular}{|c|c|c|c|c|c|c|c|}
\hline \multicolumn{8}{|c|}{ Coefficients $^{a}$} \\
\hline \multirow[b]{2}{*}{ Model } & \multicolumn{2}{|c|}{$\begin{array}{l}\text { Unstandardized } \\
\text { Coefficients }\end{array}$} & \multirow{2}{*}{$\begin{array}{c}\begin{array}{c}\text { Standardized } \\
\text { Coefficients }\end{array} \\
\text { Beta }\end{array}$} & \multirow[b]{2}{*}{$\mathbf{t}$} & \multirow[b]{2}{*}{ Sig. } & \multicolumn{2}{|c|}{$\begin{array}{c}\text { Collinearity } \\
\text { Statistics }\end{array}$} \\
\hline & B & $\begin{array}{l}\text { Std. } \\
\text { Error }\end{array}$ & & & & Tolerance & VIF \\
\hline (Constant) & 7.003 & 3.105 & & 2.256 & .026 & & \\
\hline JI & .454 & .138 & .297 & 3.281 & .001 & .793 & 1.262 \\
\hline EM & -.281 & .095 & -.272 & -2.954 & .004 & .765 & 1.306 \\
\hline PS & .088 & .048 & .158 & 1.841 & .068 & .878 & 1.139 \\
\hline
\end{tabular}

a. Dependent Variable: TI

Sumber: Hasil pengolahan data 
Analisis kolinearitas antar variable independent dari sampel yang diteliti pada penelitian ini menunjukkan tidak adanya multikolienaritas, antar masingmasing variable independent, yang ditunjukkan dengan tingginya angka toleransi dengan nilai $>0,1$ dan rendahnya angka Variance Inflation Factor (IVF) dengan nilai <10. Variabel independent Job Insecurity memiliki nilai tolerance 0,739 $(>0,1)$ dan VIF 1,262 $(<10)$, variable Employee Morale memiliki nilai tolerance 0,765 dan VIF 1,306, dan variable Psychological Strain memiliki nilai tolerance 0,878 dan VIF 1,139. Dapat disimpulkan dari hasil pengujian ini karena rendahnya angka multikolinearitas dari ketiga variable independent di atas maka standar error penelitian ini kecil.

\section{4) Uji Heteroskedastisitas}

Uji heteroskedastisitas bertujuan untuk menguji apakah dalam model regresi linear terjadi ketidaksamaan varians dari residual satu pengamatan ke pengamatan yang lain. Pengujian heteroskedastisitas menggunakan grafik scatterplot. Berikut output uji heteroskedastisitas menggunakan grafik scatterplot:

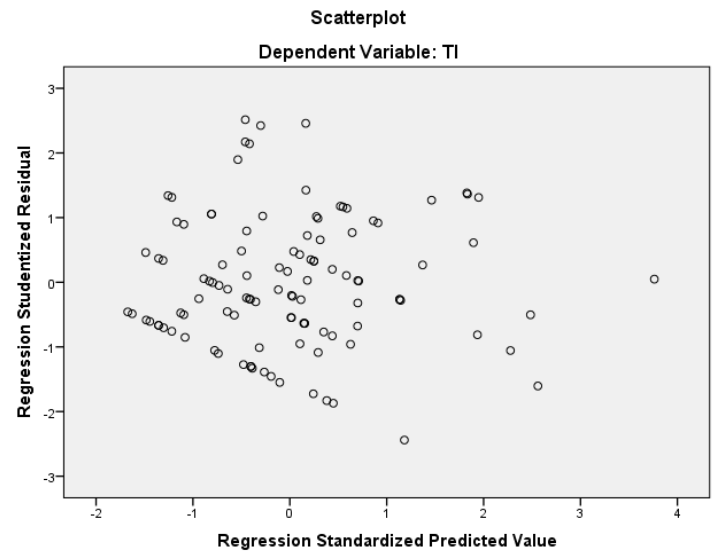

Grafik 3

Scatterplot

Sumber: Hasil pengolahan data

Dari output di atas, terlihat bahwa persebaran data berada di atas dan di bawah nilai 0 yang berarti tidak terjadi heteroskedastisitas dalam model penelitian ini. Pada pengujian heteroskedastisitas, jika dilihat kembali persebaran titik-titik pada grafik 4.3 diatas, tidak menunjukkan pola tertentu melainkan tersebar di atas dan di bawah angka 0 menunjukkan bahwa sampel penelitian ini dapat dijadikan model penelitian yang baik.

\section{B. Pembahasan}

\section{1) Pengaruh Job Insecurity terhadap Employee Morale perawat}

Hasil pengujian Hipotesis 1 (H1) membuktikan bahwa Job Insecurity, perasaan/ asumsi tidak aman yang dirasakan oleh perawat yang terkait dengan 
Pengaruh Job Insecurity terhadap Turnover Intention dengan Employee Morale dan Psychological Strain sebagai Variabel Mediasi pada Profesi Keperawatan di Jakarta

pekerjaannya mempengaruhi secara signifikan employee morale atau moral kerja atau keterlibatan/ engagement perawat tersebut. Job insecurity di pada perawat yang bekerja di Rumah Sakit seperti telah dijelaskan pada bab 2 disebabkan oleh beberapa factor. Resiko akan kehilangan pekerjaan dan ketidakpastian akan masa depan merupakan salah satu factor yang mempengaruhi semangat/ moral perawat dalam bekerja. Menurut (Beyea, 2004), individu dengan kondisi moral yang rendah beresiko kehilangan minat mereka dalam bekerja, namun seringkali bukannya mencari tempat kerja atau posisi yang baru mereka justru tetap masuk bekerja namun dengan kondisi tidak bahagia. Kondisi moral kerja yang rendah dapat memberikan kinerja yang kurang baik dalam hal ini juga pada perawatan pasien (Dyerbye et al, 2017).

Hubungan job insecurity terhadap keterlibatan di pekerjaan/ job engagement didapatkan dari hasil meta-analysis (Cheng \& Chan, 2008). Pada masa pandemic covid19 saat ini berdasarkan study kepada 474 responden di Amerika, mereka mengalami job insecurity sebagai dampak dari pandemic (Wilson et al., 2020). Pada karyawan perhotelan yang diteliti di China oleh (Jung, Jung, \& Yoon, 2021) Job insecurity berdampak pada penurunan engagement pekerja, dan engagement tersebut menjadi variable mediasi yang kuat antara job insecurity dengan turnover intention, terutama yang terdampak pandemic Covid19. Dampak penurunan engagement tersebut terjadi terutama pada pekerja usia $>35$ tahun.

Pada penelitian terhadap profesi radiographer yang bekerja di Rumah Sakit yang mengoperasikan mobile x-ray untuk pemeriksaan pasien Covid19, ketidakamanan bekerja dan penurunan moral terjadi di awal pandemic saat terjadi kelangkaan alat pelindung diri (APD) (Yasin, Barlow, \& Milner, 2021).

Pentingnya employee morale terutama perawat yang mayoritas waktu kerjanya menghadapi pasien secara tatap muka terutama berkaitan dengan Patient Safety/ keselamatan pasien (Beyea, 2004). Resiko terjadinya insiden akan meningkat. Sehingga Rumah Sakit sebagai sebuah institusi pelayanan kesehatan perlu memperhatikan hal ini. Ketidakamanan dalam bekerja karena sebab apapun perlu diidentifikasi dan ditangani agar mengurangi resiko penurunan moral kerja perawat yang dapat meningkatkan resiko terhadap keselamatan pasien.

\section{2) Pengaruh Job Insecurity terhadap Psychological Strain Perawat.}

Hasil pengujian Hipotesis 2 (H2) membuktikan bahwa Job Insecurity, selain mempengaruhi employee moral seperti dibahas di atas, juga mempengaruhi psychological strain. Security atau keamanan adalah salah satu kebutuhan dasar manusia sesuai dengan kriteria Maslow. Saat dihadapkan pada kondisi ketidakpastian atau terancam akan menimbulkan perasaan atau asumsi tidak aman/ insecure termasuk kondisi pandemic seperti 
yang kita alami saat ini.

Di masa pandemic Covid19 terutama di masa-masa awal pandemic sekitar bulan Januari sampai dengan Maret 2020, banyak kondisi di rumah sakit yang berdampak kepada kondisi psychological perawat yang bekerja di rumah sakit. Merasa panik, tidak aman (insecure), depresi, bahkan merasa ketakutan ditemukan pada penelitian di Pakistan terhadap 76 perawat yang merawat pasien-pasien covid19 (Rheinbay et al., 2020).

Kondisi banyak tenaga kesehatan yang terpapar juga meningkatkan rasa tidak aman dan stress. Penelitian di Wuhan pada awal tahun 2020 menemukan bahwa perawat-perawat yang menangani pasien Covid19 di Wuhan mengalami stress yang disebabkan karena jam kerja yang tinggi, merasa sendiri, tidak ada keluarga, dan perasaan cemas. Begitu juga yang ditemukan pada penelitian di Italia pada Maret 2020 terhadap tenaga-tenaga kesehatan di garda depan termasuk di antaranya perawat, dokter umum, dokter Spesialis, dan lain-lain. Ditemukan beberapa gejala atau kondisi psikologis seperti PTSD, depresi, cemas, dan gangguan tidur, dan gejala tersebut semakin meningkat jika terpapar dengan relasi/ sejawat/ rekan kerja mereka terpapar bahkan sampai dengan meninggal dunia (Michelozzi et al., 2020).

3) Pengaruh Employee Morale terhadap Turnover Intention Perawat yang Bekerja di Rumah Sakit.

Penurunan moral kerja ditunjukkan dengan kehilangan semangat kerja, motivasi dan antusiasme bekerja, serta inovasi dan kreatifitas. Pada tahun 2020, Nursing Solutions, sebuah Lembaga di Amerika menyampaikan turnover rate perawat (registered nurse) di Amerika berkisar di angka 18,7\%, meningkat sekitar 2\% jika dibandingkan kondisi pada tahun 2019, dengan yang terbanyak adalah yang menempati posisi di area gawat darurat (NSI Nursing Solutions, 2021). Data turnover perawat di Indonesia tidak didapatkan oleh peneliti, sehingga menjadi kesulitan untuk dibandingkan. Yang menjadi factor terjadinya turnover di Amerika, banyak generasi Y yang memutuskan untuk mengambil pension sesuai waktunya dan tidak memperpanjang masa dinasnya karena kondisi pandemic Covid19.

Kondisi pandemic, dengan tidak sedikit tenaga kesehatan termasuk perawat yang terpapar menyebabkan ada masa dimana terjadi keterbatasan jumlah tenaga kesehatan yang bertugas jika diantara mereka ada yang tidak dapat bertugas karena harus isolasi mandiri atau bahkan dirawat. Kemudian, bertugas dengan menggunakan hazmat dan masker serta gogles membuat aktifitas pekerjaan menjadi relative lebih sulit. Apalagi petugas yang dinas di kamar perawatan Covid19, karena area tugas mereka adalah area infeksius (airborne) maka alat pelindung diri tidak bisa bebas untuk buka-pasang, sehingga menyulitkan mereka untuk makan atau minum, sulit untuk buang air kecil dan air besar. Kondisi ini menyebabkan peningkatan beban kerja dan 
Pengaruh Job Insecurity terhadap Turnover Intention dengan Employee Morale dan Psychological Strain sebagai Variabel Mediasi pada Profesi Keperawatan di Jakarta

stress kerja. Tingginya workload adalah salah satu factor yang mencetuskan seringnya keinginan untuk mengundurkan diri (Lee et al., 2017).

Dalam buletinnya, International Council of Nurses menyebutkan berdasarkan survey yang mereka selenggarakan di akhir 2020, penyebab perawat meninggalkan pekerjaannya adalah tingginya beban kerja, kekurangan peralatan, burnout, dan juga stress kerja (International Council Of Nurses, 2021).

Penelitian di Filipina ditemukan bahwa perasaan takut tertular virus Covid19 juga mempengaruhi keinginan untuk pergi baik dari tempat kerja ( $\beta$ $=0.298 ; \mathrm{p}=0.001)$ maupun dari profesinya sebagai perawat $(\beta=0.219 ; \mathrm{p}=$ 0.001), selain menurunkan tingkat kepuasan bekerja dan meningkatkan psychological distress (Labrague \& de Los Santos, 2021).

4) Pengaruh Psychological Strain terhadap Turnover Intention Perawat yang Bekerja di Rumah Sakit.

Penelitian terhadap 1840 tenaga kesehatan dari 6 rumah sakit di Jerman pada periode 2015-2016 menemukan bahwa 1 dari 6 tenaga kesehatan yang mengalami gejala-gejala burnout memiliki intensi untuk mengundurkan diri baik dari pekerjaannya maupun profesinya, untuk perawat dan bidan berkisar di angka 28,7\% (Lee et al., 2017).

Menurut (Kocaman \& Yürümezoğlu, 2015) menemukan predictor, yaitu kondisi-kondisi yang akan meningkatkan resiko perawat untuk undur diri, yaitu: masa kerja, perasaan kecewa, kelelahan secara emosional, depersonalisasi, hubungan dokter dan perawat, serta jumlah ketenagaan. Kondisi-kondisi tersebut yang sedikit banyak akan mempengaruhi suasana kerja dan secara langsung maupun tidak langsung mempengaruhi kondisi psikologis perawat tersebut.

5) Pengaruh job insecurity mempengaruhi turnover intention dengan employee morale sebagai mediasi pada perawat yang bekerja di Rumah Sakit.

Employee morale memediasi pengaruh job insecurity perawat terhadap keinginan untuk undur diri perawat tersebut. Seperti dijelaskan diatas bahwa kondisi yang tidak aman, nyaman yang berhubungan dengan pekerjaannya atau relasi dengan sesame pekerja dapat mempengaruhi secara negative moral kerja perawat tersebut sehingga mempengaruhi semangat kerja, motivasi, kreatifitas dan inovasi di tempat kerja. Bahkan perawat tersebut akan sering berpikir untuk mengundurkan diri, bisa dari organisasinya bahkan juga profesi yang digelutinya saat ini. (Mosadeghrad, Ferlie, \& Rosenberg, 2011) pada penelitiannya tentang turnover intention pada 629 staf rumah sakit di Iran pada tahun 2005 menyebutkan bahwa ketidakpuasan staf rumah sakit dalam pekerjaan akan menurunkan tingkat komitmen afeksi, normative, dan keberlanjutan staf terhadap rumah sakit dimana perawat tersebut bekerja. Pada industry perhotelan di Korea yang sangat terdampak pandemic Covid-19 
karena harus melakukan lockdown menyebabkan persepsi insecurity diantara para karyawan yang memiliki efek negative terhadap moral kerja karyawan (Jung HS et all, 2021). Dari penelitian di tanah air didapatkan tingkat stress yang cukup tinggi (36\%) pada perawat IGD di RSUD di Pamekasan (Puspitasari, Suprayitno, \& Bustami, 2021).

Usaha untuk meminimalkan rasa takut yang dialami oleh perawat saat menangani pasien Covid adalah dengan penggunaan protokol kesehatan, melengkapi tenaga kesehatan dengan fasilitas APD lengkap, makanan yang sehat dan juga suplemen vitamin. Dukungan, support moral dari organisasi profesi keperawatan juga senantiasa disampaikan oleh Ketua Perhimpunan Perawat Nasional Indonesia - PPNI (covid19.go.id, 2021).

6) Pengaruh job insecurity mempengaruhi turnover intention dengan psychological strain sebagai mediasi pada perawat yang bekerja di Rumah Sakit.

Dari hasil ini dapat kita lihat bahwa ternyata variable psychological strain bukan merupakan variable yang memediasi hubungan antara job insecurity dengan turnover intention. Walaupun masing-masing variable baik Job Insecurity maupun psychological strain memiliki pengaruh positif bagi turnover intention. Perawat yang memiliki job insecurity dapat berpikir untuk undur diri. Begitu juga saat perawat mengalami atau memiliki psycological strain dengan penyebab apapun, bias memiliki intensi untuk undur diri. Krisis ekonomi akibat pandemic Covid-19 yang berdampak kepada seluruh industry termasuk juga industri hospitality juga ditunjukkan pada berbagai penelitian bagaimana dampaknya baik secara langsung maupun tidak langsung terhadap kesehatan mental psikologis pekerja (Khan, Niazi, Nasir, Hussain, \& Khan, 2021).

Pemerintah Indonesia melihat peran penting tenaga kesehatan di masa pandemic berusaha memberikan fasilitas dan insentif khusus bagi tenagatenaga kesehatan yang menangani pasien-pasien Covid-19. Peraturan tentang pemberian insentif tenaga kesehatan dan santunan kematian yang dikeluarkan pada bulan Juli 2020 (PP No.29, 2020), pemberian insentif pajak penanganan pasien Covid (KMK No.447, 2020), prioritas program pemberian vaksinasi bagi tenaga kesehatan (KMK No.12757, 2020) dengan tujuan untuk meningkatkan rasa aman dalam bekerja bagi para tenaga kesehatan. Dan dari penelitian local terhadap tenaga kesehatan di Kabupaten Minahasa Utara (Umpung, Pertiwi, \& Korompis, 2020) bahwa penerapan kebijakan yang jelas di tempat kerja, hubungan kerja yang baik, dan pemberian kompensasi/ insentif selama pandemic Covid19 mempengaruhi motivasi kerja tenaga kesehatan tersebut $(\mathrm{p}$-value $=0,000)$. Hasil yang kurang lebih sejalan juga ditemukan pada penelitian yang dilakukan pada sebuah Rumah Sakit di Banten bahwa kondisi tempat kerja (kebijakan RS, ketersediaan APD) serta dukungan rekan kerja dan atasan serta keluarga dapat menjaga motivasi kerja 
Pengaruh Job Insecurity terhadap Turnover Intention dengan Employee Morale dan Psychological Strain sebagai Variabel Mediasi pada Profesi Keperawatan di Jakarta

perawat yang bekerja di area perawatan pasien Covid-19 (Wihardja H., Arif Y.K., Lina R.N., 2021).

\section{Kesimpulan}

Dari 6 hipotesis yang diuji, hipotesis 1 sampai dengan 5 memiliki hasil yang positif, bahwa Job Insecurity mempengaruhi turnover intention dengan dimediasi oleh Employee Morale, sementara aspek atau variable psychological strain tidak terbukti memediasi pengaruh job insecurity terhadap turnover intention. Penelitian yang dilakukan menunjukan bahwa sebagian besar perawat di rumah sakit Jakarta memiliki presepsi akan adaya alternative pekerjaan lainnya. Presepsi tersebut telah dibuktikan akan mempengaruhi hubungan antara Job insecurity, Employee Morale, Psychological Strain terhadap Turnover Intention.

Beberapa strategi dapat dilakukan oleh pihak manajemen rumah sakit untuk menurunkan tingkat hasrat undur diri yang dirasakan perawat sebagai dampak dari kondisi eksternal (pandemic covid) yang berdampak kepada kondisi internal Rumah Sakit. Opsi memberikan kontrak jangka panjang kepada karyawan dengan jaminan tidak akan memutus kontrak secara sepihak, memberikan jalur kerja yang jelas kepada perawat seperti bekerja sama dengan rumah sakit-rumah sakit yang dapat meningkatkan kemampuan perawat, serta memberikan motivasi melalui kepala perawat untuk tetap optimis yang dapat dilakukan pada setiap sesi pertemuan, briefing, atau rapat. Penyediaan Alat Pelindung Diri (APD) yang sesuai, pemberian suplemen tambahan seperti vitamin, cemilan, dan juga pelatihan atau program-program peningkatan kompetensi secara berkala juga dapat menjadi salah satu opsi untuk menurunkan turnover intention perawat di Rumah Sakit di Jakarta.

Terdapat beberapa limitasi atau keterbatasan yang dapat menjadi peluang untuk pengembangan penelitian di masa yang akan datang. Jumlah sample yang tidak mencapai target, yang mungkin dapat mempengaruhi hasil/ model yang terbentuk. Hal ini bisa dilihat pada nilai $\mathrm{R}$ square yang lemah, yang belum cukup kuat menggambarkan hubungan antar variable. Kemudian kesulitan pengumpulan sample karena Pemberlakuan Pembatasan Kegiatan Masyarakat (PPKM) sehingga pengumpulan sample tidak berjalan dengan optimal, usaha komunikasi melalui email tidak mendapatkan respon seperti yang diharapkan. Penelitian mengenai job insecurity dan turnover intention kali ini tidak menganalisa variabel status kepegawaian dan masa kerja. Status pegawai tetap atau kontrak serta masa kerja ada kemungkinan juga mempengaruhi variable job insecurity dan turnover intention. Kerangka waktu pengambilan sample. Pengambilan sample dilakukan setelah hampir 1 tahun pandemic Covid19 berjalan, sehingga hanya dapat menggambarkan kondisi pada saat itu dimana sudah dilakukan program-program retensi baik dari Rumah Sakit maupun dari Pemerintah untuk meningkatkan kesehatan dan keamanan kerja tenaga kesehatan, termasuk peningkatan pemahaman terkait penyakit dan penyebarannya. 


\section{BIBLIOGRAFI}

Beyea, Suzanne C. (2004). Employee morale and patient safety. AORN Journal, 80(6), 1123-1126.Google Scholar

Cheng, Grand H-L, \& Chan, Darius K-S. (2008). Who suffers more from job insecurity? A meta-analytic review. Applied Psychology, 57(2), 272-303. Google Scholar

Feng, Wong Chyi, \& Angeline, Tay. (2010). Turnover intention and job hopping behaviour of music teachers in Malaysia. African Journal of Business Management, 4(4), 425-434. Google Scholar

Giantari, Ida Ayu Indah, \& Riana, I. Gede. (2017). Pengaruh budaya organisasi terhadap motivasi kerja dan kinerja karyawan Klumpu Bali Resort Sanur. E-Jurnal Manajemen Unud, 6(12), 6471-6498. Google Scholar

International Council Of Nurses. (2021). International Council Of Nurses Policy Brief: The Global Nursing Shortage And Nurse Retention.

Jung, Hyo Sun, Jung, Yoon Sik, \& Yoon, Hye Hyun. (2021). COVID-19: The effects of job insecurity on the job engagement and turnover intent of deluxe hotel employees and the moderating role of generational characteristics. International Journal of Hospitality Management, 92, 102703. Google Scholar

Khan, Kanwal Iqbal, Niazi, Amna, Nasir, Adeel, Hussain, Mujahid, \& Khan, Maryam Iqbal. (2021). The Effect of COVID-19 on the Hospitality Industry: The Implication for Open Innovation. Journal of Open Innovation: Technology, Market, and Complexity, 7(1), 30. Google Scholar

Kocaman, Gülseren, \& Yürümezoğlu, Havva Arslan. (2015). Türkiye'de Hemşirelik Eğitiminin Durum Analizi: Sayılarla Hemşirelik Eğitimi 1996-2015. Yükseköğretim ve Bilim Dergisi, (3), 255-262. Google Scholar

Labrague, Leodoro J., \& de Los Santos, Janet Alexis A. (2021). Fear of Covid-19, psychological distress, work satisfaction and turnover intention among frontline nurses. Journal of Nursing Management, 29(3), 395-403. Google Scholar

Lee, Ya-Wen, Dai, Yu-Tzu, Chang, Mei Yeh, Chang, Yue-Cune, Yao, Kaiping Grace, \& Liu, Mei-Chun. (2017). Quality of work life, nurses' intention to leave the profession, and nurses leaving the profession: A one-year prospective survey. Journal of Nursing Scholarship, 49(4), 438-444. Google Scholar

Michelozzi, Paola, de'Donato, Francesca, Scortichini, Matteo, De Sario, Manuela, Noccioli, Fiammetta, Rossi, Pasqualino, \& Davoli, Marina. (2020). Mortality impacts of the coronavirus disease (COVID-19) outbreak by sex and age: rapid mortality surveillance system, Italy, 1 February to 18 April 2020. Eurosurveillance, 25(19), 2000620. Google Scholar 
Pengaruh Job Insecurity terhadap Turnover Intention dengan Employee Morale dan Psychological Strain sebagai Variabel Mediasi pada Profesi Keperawatan di Jakarta

Mosadeghrad, Ali Mohammad, Ferlie, Ewan, \& Rosenberg, Duska. (2011). A study of relationship between job stress, quality of working life and turnover intention among hospital employees. Health Services Management Research, 24(4), 170181. Google Scholar

Nasehudin, Toto Syatori, \& Gozali, Nanang. (2012). Metode penelitian kuantitatif. Google Scholar

NSI Nursing Solutions, Inc. (2021). NSI National Health Care Retention \& RN Staffing Report. Google Scholar

Obeng, Anthony Frank, Quansah, Prince Ewudzie, \& Boakye, Eric. (2020). The Relationship between Job Insecurity and Turnover Intention: The Mediating Role of Employee Morale and Psychological Strain. Management, 10(2), 35-45. Google Scholar

Puspitasari, Dian Ika, Suprayitno, Emdat, \& Bustami, Bustami. (2021). Tingkat Stres Kerja Perawat Instalasi Gawat Darurat pada Masa Pandemi Covid-19. Wiraraja Medika: Jurnal Kesehatan, 11(1), 25-29. Google Scholar

Ramayah, T., Cheah, Jacky, Chuah, Francis, Ting, Hiram, \& Memon, Mumtaz Ali. (2018). Partial least squares structural equation modeling (PLS-SEM) using smartPLS 3.0. Kuala Lumpur: Pearson. Google Scholar

Rheinbay, Esther, Nielsen, Morten Muhlig, Abascal, Federico, Wala, Jeremiah A., Shapira, Ofer, Tiao, Grace, Hornshøj, Henrik, Hess, Julian M., Juul, Randi Istrup, \& Lin, Ziao. (2020). Analyses of non-coding somatic drivers in 2,658 cancer whole genomes. Nature, 578(7793), 102-111. Google Scholar

Richter, Anne, Näswall, Katharina, \& Sverke, Magnus. (2010). Job insecurity and its relation to work-family conflict: Mediation with a longitudinal data set. Economic and Industrial Democracy, 31(2), 265-280.

Saputra, Pramana, Sudiro, Achmad, \& Irawanto, Dodi W. (2018). Job satisfaction in compensation, environment, discipline, and performance: evidence from Indonesia higher education. MEC-J (Management and Economics Journal), 2(3), 217-236. Google Scholar

Sarwono, Jonathan. (2012). Metode Riset Skripsi Pendekatan Kuantitatif (Menggunakan Prosedur SPSS): Tuntunan Praktis dalam Menyusun Skripsi. Google Scholar

Sekaran, Uma, \& Bougie, Roger. (2019). Research methods for business: A skill building approach. john wiley \& sons. Google Scholar

Sugiyono, Prof. (2015). Metode penelitian kombinasi (mixed methods). Bandung: Alfabeta, 28, 1-12. Google Scholar

Umpung, Festy Debora, Pertiwi, Junita Maya, \& Korompis, Grace Ester Caroline. (2020). Faktor-Faktor yang Mempengaruhi Motivasi Kerja Tenaga Kesehatan di 
Puskesmas Kabupaten Minahasa Tenggara Pada Masa Pandemi Covid 19. Indonesian Journal of Public Health and Community Medicine, 1(4), 18-27. Google Scholar

Wilson, Jenna M., Lee, Jerin, Fitzgerald, Holly N., Oosterhoff, Benjamin, Sevi, Baris, \& Shook, Natalie J. (2020). Job insecurity and financial concern during the COVID-19 pandemic are associated with worse mental health. Journal of Occupational and Environmental Medicine, 62(9), 686-691. Google Scholar

Yasin, Bushra, Barlow, Nicholas, \& Milner, R. (2021). The impact of the Covid-19 pandemic on the mental health and work morale of radiographers within a conventional X-ray department. Radiography. Google Scholar

\section{Copyright holder:}

Hutri Mardika RM, Yustinus H Yogatama (2021)

First publication right:

Syntax Idea

This article is licensed under: 